\title{
ФАНДРАЙЗИНГ СОЦІАЛЬНИХ ПРОЄКТІВ ЯК ІНСТРУМЕНТ СОЦІАЛЬНОГО РОЗВИТКУ ТЕРИТОРІАЛЬНИХ ГРОМАД
}

\author{
Алена Ревко, Екатерина Чумак \\ ФАНДРАЙЗИНГ СОЦИАЛЬНЫХ ПРОЕКТОВ КАК ИНСТРУМЕНТ \\ СОЦИАЛЬНОГО РАЗВИТИЯ ТЕРРИТОРИАЛЬНЫХ ОБЩИН
}

\author{
Alona Revko, Kateryna Chumak \\ FUNDRAISING OF SOCIAL PROJECTS AS AN TOOL OF SOCIAL \\ DEVELOPMENT OF TERRITORIAL COMMUNITIES
}

\begin{abstract}
Стаття присвячена дослідженню особливостей використання фандрайзингу соиіальних проєктів як засобу забезпечення розвитку сочіальних послуг територіальних громад та формування активного громадянського суспільства. Обтрунтовано, що фандрайзингова діяльність може передбачати залучення не лише фінансових ресурсів від приватних осіб або організаиій, але й залучення людей та організацій для реалізації певних сочіальних проєктів та програм. Визначено, що провідними суб 'єктами фандрайзингової діяльності в Україні є неприбуткові організації, щяо займаються пошуком джерел фінансування та інших необхідних ресурсів для реалізації своїх соціальних проєктів. Проведено емпіричне дослідження з метою визначення особливостей реалізаиії фандрайзингової діяльності Чернігівського міського центру сочіальних служб для сім'ї, дітей та молоді як закладу, який опікується вирішення соиіальних проблем мешканців Чернігівської громади. Встановлено, що основною формою фандрайзингу Центру є оперативна, тобто залучення ресурсів на певні потреби організації та клієнтів, щзо передбачає адресне використання коштів. Доведено, що більшість співробітників Центру, які займаються фандрайзинговою діяльністю, не мають спеціальної підготовки і використовують ией вид діяльності інтуїтивно. Мотивами їхньої роботи є прагнення допомогти клієнтам, які перебувають у складних життєвих обставинах.
\end{abstract}

Ключові слова: фандрайзинг; сочіальний проєкт; територіальна громада; децентралізація.

Рис: 2. Бібл.: 10.

Статья посвящена исследованию особенностей использования фандрайзинга социальных проектов как средства обеспечения развития сочиальных услуг территориальных общин и формирование активного гражданского общества. Обосновано, что фандрайзинговая деятельность может предусматривать привлечение не только финансовых ресурсов от частных лии или организачий, но и привлечение людей и организаций для реализации определенных сочиильных проектов и программ. Определено, что ведущиим субъектами фандрайзинговой деятельности в Украине - это неприбыльные организачии, занимающиеся поиском источников финансирования и других необходимых ресурсов для реализации своих соииальных проектов. Проведено эмпирическое исследование с целью определения особенностей реализации фандрайзинговой деятельности Черниговского городского иентра социальных служб для семьи, детей и молодежи как учреждения, которое занимается решения соииальных проблем жителей Черниговской общины. Установлено, что основной формой фандрайзинга Центра является оперативная, то есть привлечения ресурсов на определенные нужды организации и клиентов, предусматривает адресное использование средств. Доказано, что большинство сотрудников Центра, которые занимаются фандрайзинговой деятельностью, не имеют специальной подготовки и используют этот вид деятельности интуитивно. Мотивами их работы является стремление помочь клиентам, которые находятся в сложных жизненных обстоятельствах.

Ключевые слова: фандрайзинг; сочиальный проект; территориальная община; децентрализачия.

Рис: 2. Библ.: 10.

The article is devoted to the study of the peculiarities of the use of fundraising of social projects as a means of ensuring the development of social services of territorial communities and the formation of an active civil society. It is substantiated that fundraising activities may involve not only the attraction of financial resources from individuals or organizations, but also the involvement of people and organizations for the implementation of certain social projects and programs. It is determined that the leading subjects of fundraising activities in Ukraine are non-profit organizations that are looking for sources of funding and other necessary resources for the implementation of their social projects. An empirical study was conducted to determine the specifics of the fundraising activities of the Chernihiv City Center for Social Services for Families, Children and Youth as an institution that cares about solving social problems of residents of the Chernihiv community. It is established that the main form of fundraising of the Center is operational, ie attracting resources for certain needs of the organization and clients, which involves the targeted use of funds. It has been proven that most of the Center's employees who are engaged in fundraising activities do not have special training and use this type of activity intuitively. The motives of their work are the desire to help clients who are in difficult life circumstances.

Keywords: fundraising; social project; local community; decentralization.

Fig.: 2. References: 10

JEL Classification: A13; L31; R1 
Постановка проблеми. В умовах системної економічної кризи та, як наслідок, постійного скорочення фінансування соціальної сфери України, фандрайзинг соціальних проєктів може стати адекватним засобом забезпечення розвитку соціальних послуг територіальних громад та формування активного громадянського суспільства. Актуальність фандрайзингової діяльності посилюється і внаслідок реформи децентралізації, оскільки доволі часто об'єднаним територіальним громадам не вистачає власних ресурсів для вирішення нагальних соціальних питань. Крім того, розвиток фандрайзингу соціальних проєктів як інструменту реалізації соціально значущих програм, розвитку соціальної політики нашої держави $є$ надзвичайно актуальними 3 огляду на негативну тенденцію скорочення державних видатків на соціальну сферу.

Саме розвиток фандрайзингу соціальних проєктів в Україні має сприяти інституалізації такої діяльності і, зрештою, впливатиме на вирішення актуальних соціальних проблем у громаді.

Аналіз останніх досліджень і публікацій. Питаннями розвитку фандрайзингу та дослідженням фандрайзингової діяльності присвячені роботи провідних вітчизняних та закордонних учених, а саме: Т. Артем'євої, А. Балашової, О. Башун, А. Дугласа, К. Карлсон, С. Куц, Г. Тульчинського та інших.

Практичні аспекти застосування фандрайзингу для фінансування неурядових організацій досліджували такі науковці, як А. Саржо, Дж. Шанг, М. Огборн, О. Чернявська, А. Соколова, Б. Чиконте, Дж. Харт, С. Васильчак, М. Куницька-Іляш, П. Красномовец, А. Карпуніна, В. Огородник, Є. Холостова та інші.

Виділення недосліджених частин загальної проблеми. Незважаючи на появу останнім часом значної кількості наукових досліджень щодо фандрайзингової діяльності, іiї етапів та механізмів реалізації, фандрайзинг як інструмент реалізації соціальних проєктів в Україні мало досліджений. В Україні фандрайзингова діяльність усе ще залишається не регламентованою, немає стандартів для іiі впровадження, не розроблено нормативно-правової бази такої діяльності.

Мета статті. Головною метою цієї публікації є дослідження особливостей розбудови фандрайзингу соціальних проєктів як засобу соціального розвитку територіальних громад в умовах децентралізації.

Виклад основного матеріалу. Як зазначав М. Сендлер, «фандрайзинг - це кровоносна система (lifeblood) третього сектора» [1], тобто він є свого роду життєвою необхідністю для розвитку некомерційних організацій та територіальних громад. Це поняття вперше з'явилося у другій половині ХХ століття в США у зв'язку зі зростанням ролі третього сектору в економіці.

Поняття «фандрайзинг» походить від англійського fundraising, а саме словосполучення англійських слів «fund» (фонди або кошти) та «raise» (піднімати або збільшувати), таким чином, це залучення певних ресурсів, коштів. Однак необхідно відрізняти фандрайзинг і благодійництво. Благодійність - це безкорисна, добровільна допомога всім нужденним, а фандрайзинг - це діяльність, спрямована на залучення цієї допомоги.

О. Грабчак зауважує, що фандрайзинг - це свідома та добровільна мобілізація внутрішніх та залучення зовнішніх ресурсів для реалізації суспільно корисних ініціатив [3].

Уточнюючи сутність поняття «фандрайзинг» А. Кривоносов додає, що це діяльність, спрямована безпосередньо на збір та акумулювання ресурсів із різноманітних джерел на реалізацію соціальних проєктів і програм, які переважно не мають комерційної вигоди і мають короткочасний характер [6].

Серед трактувань поняття «фандрайзинг» поширеними $є$ й такі, що розглядають фандрайзинг як спеціально організований процес пошуку ресурсів неприбутковими організаціями для реалізації соціальних проєктів, або комплексна система заходів щодо залучення ресурсів для реалізації соціальних проєктів; професійна управлінська діяльність щодо пошуку грошових коштів. 
ПРОБЛЕМИ МЕНЕДЖМЕНТУ ТА РОЗВИТКУ ПРОДУКТИВНИХ СИЛ РЕГІОНУ

На думку Л. Лунева, фандрайзинг - це певне мистецтво залучення коштів приватних осіб чи благодійних організацій, які надають фінансові ресурси у вигляді грантів; процес збору коштів та інших ресурсів, котрі використовуються, в більшості випадків, для реалізації соціально значимих проєктів та програм» [9, с. 92].

Найбільш комплексно, на нашу думку, зазначене поняття визначено С. Холостовою, яка розглядає фандрайзинг як доволі тривалий процес взаємодії як мінімум двох сторін (фізичних або юридичних осіб); процес, метою якого $є$ збір коштів та залучення ресурсів на реалізацію соціально значущої діяльності однією стороною і прийняття рішення про їх надання іншою стороною; процес, який реалізується за участі посередників за допомогою певної процедури та розробленого механізму [10].

Зауважимо, що фандрайзингова діяльність може передбачати залучення не лише фінансових ресурсів від приватних осіб або організацій, але й залучення людей та організацій для реалізації певних соціальних проєктів та програм.

Учена А. Карпуніна [5] відносить фандрайзинг до економічної діяльності зауважуючи, що він:

1) виникає у разі усвідомлення фандрайзером обмеженості ресурсів, їх нестачі, що, у свою чергу, формує усвідомлену потребу в них;

2) є засобом задоволення потреб особистості або групи і спрямована на забезпечення їхньої життедіяльності;

3) виражається в перерозподілі ресурсів від донора до отримувача.

Тобто це поєднання економічно орієнтованих (спрямованих на забезпечення життєдіяльності) і економічно обумовлених (ненасильницького використання, перерозподілу ресурсів) дій. Дослідниця зауважує, що така діяльність здійснюється на мезорівні, проте фандрайзинг як вид економічної діяльності має певні особливості, оскільки породжується соціальними умовами i, в свою чергу, впливає на них, змінюючи та покращуючи їх.

Ю. Грищенко, аналізуючи поняття фандрайзингу зауважує, що його треба відрізняти від поняття інвестиції, оскільки метою інвесторів $є$ насамперед отримання прибутку [4].

Практика фандрайзингу в нашій країні почала поширюватися 3 появою перших некомерційних організацій та залученням перших донорів: фондів Copoca та TACIS. Зауважимо, що багато некомерційних громадських організацій в Україні виникли завдяки фінансуванню саме цих фондів.

Нині провідними суб'єктами фандрайзингової діяльності в Україні є неприбуткові організації, що займаються пошуком джерел фінансування та інших необхідних ресурсів для реалізації своїх соціальних проєктів. Як зазначає В. Луков, соціальний проєкт це сконструйована модель соціальної ініціативи, метою якої є створення нового, підтримка наявного або модернізація існуючого соціального оточення [7, с. 32]. Ця модель повинна мати просторово-часові обмеження і позитивно впливати на соціальний розвиток територіальних громад.

На думку науковців Т. Безверхнюк та А. Левицького, соціальний проєкт - це певною мірою спосіб реформування наявної системи соціального забезпечення, підвищення ефективності її функціонування [2]. Проєкт дозволяє умовно рухатись від ідеї до її реалізації за певним планом і етапами, зокрема, проєкт майже завжди виступає результатом колективної діяльності.

На наш погляд, соціальний проєкт - це певна технологія, яка надає можливість апробації соціальної ідеї. Це своєрідна інтегрована система, що підпорядковується певним цілям та завданням і реалізується згідно з розробленими та затвердженими документами: програмами, планами, кошторисами, розрахунками тощо, з урахуванням усіх наявних ресурсів: матеріальних, фінансових, трудових, часових; це комплекс управлінських рішень та заходів для досягнення визначених цілей. 
Слід зауважити, що до об'єктів фандрайзингу соціальних проєктів належать різні групи донорів, а саме, переважно благодійні та релігійні організації, громадські об'єднання, комерційні структури, органи місцевої влади, а також приватні особи. Здебільшого джерелами фінансування фандрайзингу соціальних проєктів є: проведення благодійних заходів зі збору коштів на соціальні проєкти, волонтерський рух, пожертвування, отримання грантів, участь у державних та регіональних цільових програмах, а також внески спонсорів.

Одним із закладів, який опікується вирішення соціальних проблем мешканців Чернігівської громади, $є$ Чернігівський міський центр соціальних служб для сім’ї, дітей та молоді (ЧМЦСССДМ). 3 метою визначення особливостей реалізації фандрайзингової діяльності ЧМЦСССДМ нами було проведене емпіричне дослідження. У дослідженні взяли участь працівники Центру. Вибіркова сукупність становила 20 осіб. Середній вік опитаних - 36 років.

Основним методичним інструментом дослідження особливостей фандрайзингової діяльності ЧМЦСССДМ виступила розроблена нами анкета, яка включала такі 4 основні параметри (i, відповідно, блоків питань):

1) паспортний блок;

2) запитання, спрямовані на з'ясування особливостей залучення додаткових ресурсів ЧМЦСССДМ;

3) запитання, спрямовані на діагностику підготовки співробітників для реалізації такої діяльності;

4) запитання спрямовані на визначення методів, форм, особливостей звітності щодо результатів такої роботи.

Результати анкетування засвідчили, що 80 \% респондентів знають слово «фандрайзинг», проте не можуть визначитися з його змістовим наповненням. Водночас $20 \%$ опитаних взагалі ніколи не чули такого слова. Більшість респондентів (90 \%) зауважили, що ЧМЦСССД став залучати додаткові ресурси для реалізації соціальних проєктів лише 2-3 роки тому.

Було виявлено, що об'єктами фандрайзингової діяльності більшість респондентів (85\%) називають спонсорами і тільки 10 та $5 \%$ опитаних благодійниками та донорами відповідно.

Варто зазначити, що ЧМЦСССДМ звертається за допомогою до різних типів донорів, найчастіше місцевої влади, представників політичних партій, малого та середнього бізнесу, до приватних осіб та громадських організацій. У 2020 р. працівники Центру не зверталися за допомогою до великих компаній. Благодійність комерційних компаній не має постійного характеру. Опитані назвали лише три кампанії, що постійно допомагають Центру, це - ТОВ «Лавіс», ТОВ «Сенека», ТОВ «Абрис». Дві останні кампанії займаються виготовленням та продажем продуктів харчування.

Загалом компанії вважають за краще надавати натуральну допомогу у вигляді своєї продукції (так зазначили 85 \% опитаних), менш популярні форми: грошова - надання грошових коштів (5\%) та оплата товарів/послуг інших компаній (5\% опитаних) (рис. 1).

Респонденти наголошують про доволі низьку результативність звернень за допомогою до комерційних компаній. Так, в особистому інтерв'ю респонденти зауважили, що в середньому з десяти звернень до різних кампаній лише одна погоджується надати допомогу. 
ПРОБЛЕМИ МЕНЕДЖМЕНТУ ТА РОЗВИТКУ ПРОДУКТИВНИХ СИЛ РЕГІОНУ

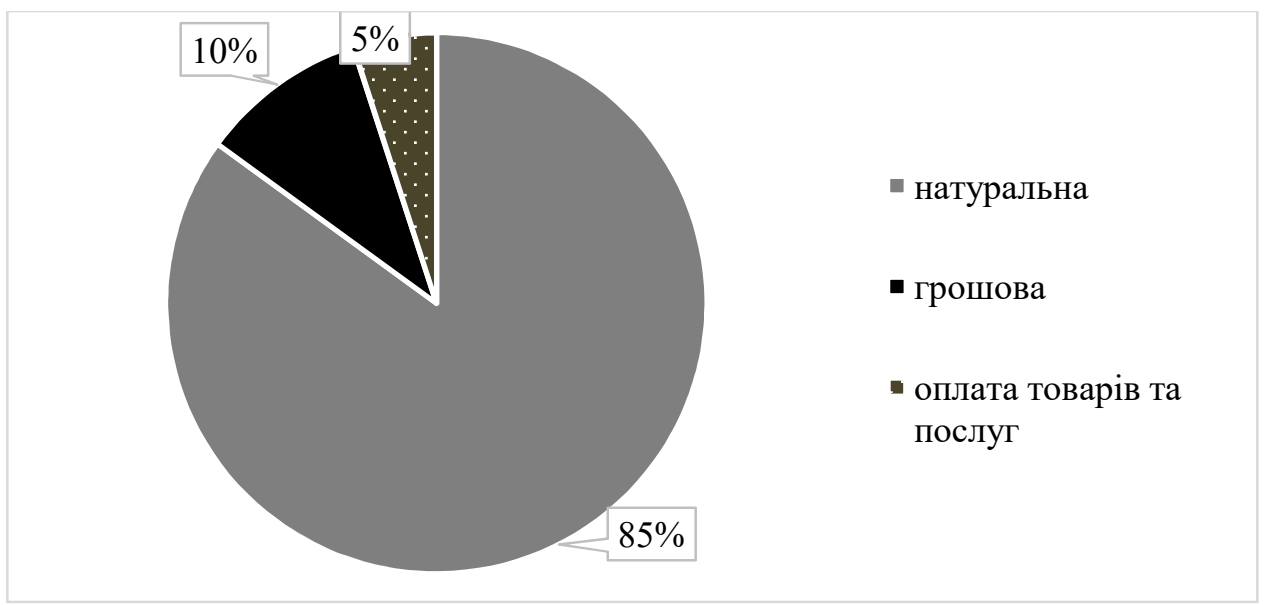

Рис. 1. Форми допомоги ЧМЦСССД від фандрайзерів

Джерело: розроблено авторами.

До головних цілей фандрайзингової діяльності ЧМЦСССДМ більшість респондентів відносить більш ефективне надання допомоги клієнтам Центру (80 \% опитаних) та по $10 \%$ опитаних вважають, що це вирішення соціальних проблем громади та досягнення загальних цілей установи (рис. 2).

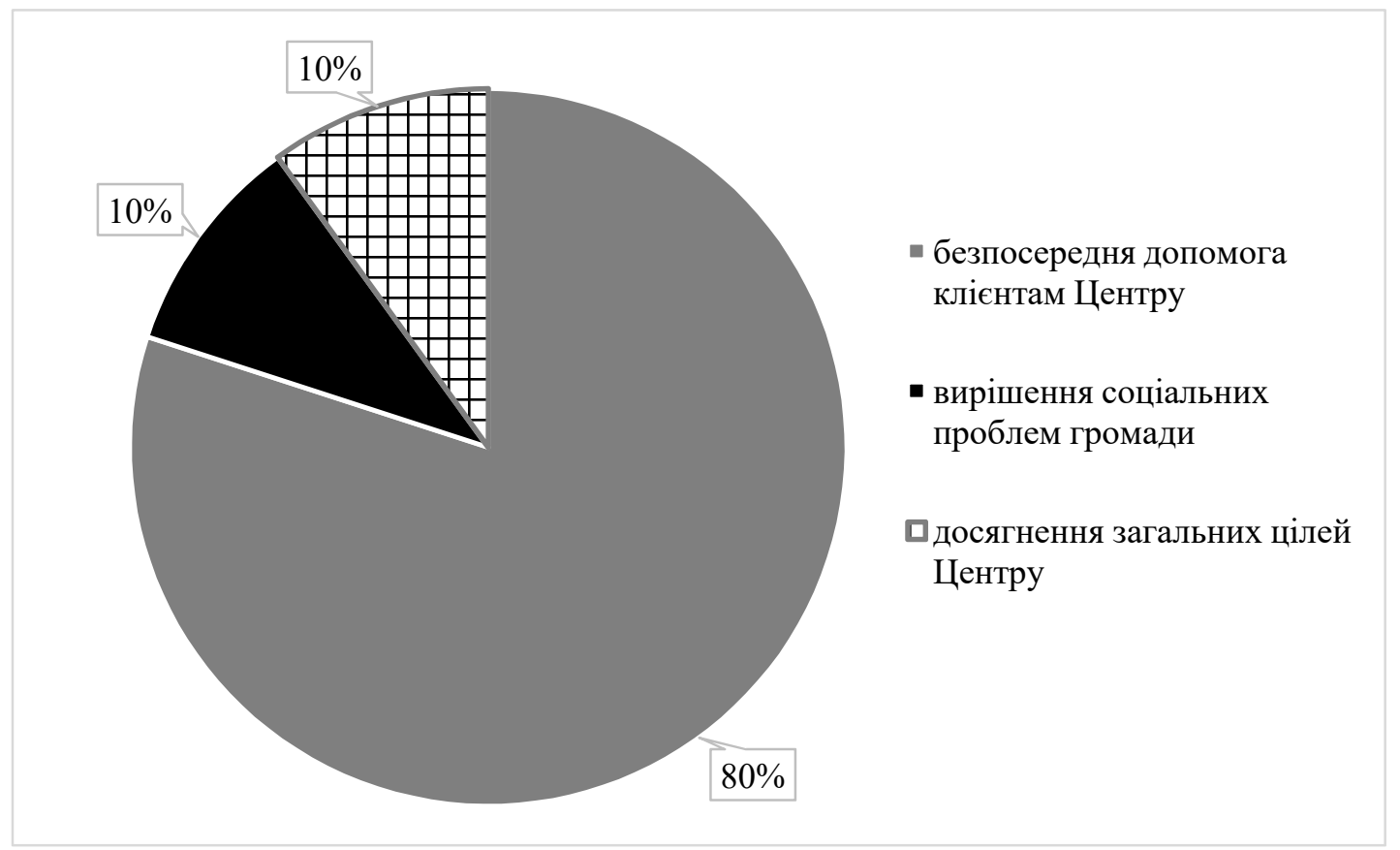

Рис. 2. Цілі фандрайзингової діяльності ЧМЦСССД

Джерело: розроблено авторами.

Слід зазначити, що на запитання про те, чи достатньо в мережі Інтернет даних про роботу ЧМСССДМ для ефективної реалізації фандрайзингової діяльності, 100 \% респондентів зауважило, що ні.

Щодо теоретичної підготовки, то теорію фандрайзингу вивчали самостійно $30 \%$ опитаних, 15 \% 3 нею ознайомилися під час навчання у вищій школі, 65 \% зазначило, що хотіло б отримати відповідні знання.

Останній блок нашої анкети був присвячений дослідженню методів та форм фандрайзингової діяльності ЧМЦСССДМ. Так, нами було з'ясовано, що комерційні компанії самостійно практично не звертаються до ЧМЦСССДМ з пропозицією надати допомогу, тож співробітники ЧМЦСССДМ активно використовують методи звернення до них. 
Найбільш поширений метод звернення - особиста зустріч (так зазначило 55 \% респондентів), телефонний дзвінок (відповідно - 45 \% респондентів). Тобто співробітники ЧМЦСССД для здійснення фандрайзингової діяльності використовують найбільш ефективний, проте і найбільш витратний метод.

Основною формою фандрайзингу в ЧМЦСССДМ є оперативна, тобто залучення ресурсів на певні потреби організації та клієнтів, що передбачає адресне використання коштів. Проєктним фандрайзингом займається лише 10 \% респондентів.

Отже, у результаті проведеного дослідження, до головних проблем реалізації фандрайзингу соціальних проєктів в Україні, на наше переконання, можна віднести:

1) загальнодержавні проблеми (проблеми макросередовища):

- відсутність єдиних нормативів, затверджених стандартів, керівних документів, законодавчого регулювання особливостей залучення ресурсів установами, котрі надають соціальні послуги членам громад;

- відсутність розроблених регіональних баз даних донорів та статистичних даних щодо обсягів залучених ресурсів на реалізацію соціальних проєктів.

2) проблеми громад (проблеми мезосередовища):

- низький рівень поінформованості населення про особливості діяльність закладів соціальної сфери, нерозуміння важливості їх роботи, впевненість населення в достатності їх державного фінансування;

- нестача ресурсів у середнього і малого бізнесу, приватних осіб унаслідок економічної кризи;

- низький рівень розвитку інфраструктури, мала кількість компаній і підприємств у локальній місцевості.

3) проблеми закладів соціальної сфери України (проблеми мікросередовища):

- відсутність посади фандрайзер у штатному розкладі більшості таких закладів;

- недостатній рівень уваги до стимулювання та розвитку фандрайзингової діяльності, іiї потенційних можливостей з боку керівництва закладів, слабкий розвиток систем підтримки і стимулювання співробітників, які опікуються такою роботою;

- низький рівень професіоналізму у фандрайзерів, якими доволі часто стають випадкові співробітники закладу, недоліки знань і досвіду, інтуїтивне ведення діяльності;

- відмова від використання організаційних методів, від менеджменту фандрайзингу, від ведення баз даних, використання сайтів, чітких форм звітності;

- психологічні труднощі фандрайзерів при роботі з донорами (страх відмови, моральні незручності).

Зауважимо, що фандрайзингова діяльність установ соціального захисту України ускладнюється і через те, що благодійництво значно менше поширене в Україні, ніж у Європі. Так, відповідно до світового рейтингу розвитку благодійної діяльності країни світу умовно можна поділити на три групи:

1) країни з високим рівнем розвитку традицій благодійності: М'янма, США, Австралія, Нова Зеландія, Шрі-Ланка, Канада, Індонезія, Великобританія, Ірландія, та інші;

2) країни із середнім рівнем розвитку інституту благодійності: Таїланд, Німеччина, Угорщина, Греція та інші;

3) країни з низьким рівнем - Україна, Росія, Казахстан, Польща, Китай, Туреччина, Португалія, Болгарія [5, с. 89].

Крім того, на нашу думку, для України характерна і недовіра до бізнесу та донорів, багатих людей загалом, i, як наслідок, несприйняття їх як можливих благодійників, здатних допомогти. 
ПРОБЛЕМИ МЕНЕДЖМЕНТУ ТА РОЗВИТКУ ПРОДУКТИВНИХ СИЛ РЕГІОНУ

Зауважимо, що хоча у своїй більшості фандрайзингова діяльність закладами соціальної сфери реалізується хаотично, досвідчені співробітники закладів соціальної сфери України, які отримали відповідну освіту в цій галузі дотримуються таких принципів фандрайзингу соціальних проєктів: поєднання стратегічної цілі та тактики, збалансованість, відповідність планів та можливостей як донорів, так установи соціальної сфери, комплексність, співпраця з партнерами, некомерційність, прозорість такої діяльності.

Висновки і пропозиції. Отже, фандрайзинг соціальних проєктів - це професійна діяльність, спрямована на залучення грошових та інших ресурсів (людських, матеріальних, інформаційних тощо) із зовнішніх джерел, які $є$ необхідними для вирішення соціальних проблем територіальних громад.

Дослідження особливостей реалізації фандрайзингової діяльності ЧМЦСССДМ дає підстави для висновку про те, що вона має епізодичний характер. Головними об'єктами фандрайзингової діяльності є приватні особи, кандидати в депутати, благодійні організації. Більшість співробітників, котрі займаються фандрайзинговою діяльністю не мають спеціальної підготовки і використовують цей вид діяльності інтуїтивно. Мотивами їх роботи є прагнення допомогти клієнтам, які перебувають у складних життєвих обставинах.

Важливим поштовхом для розвитку фандрайзингової діяльності в Україні має бути досконале опанування іiї методиками фахівцями, орієнтація не лише на приватних осіб, а й на великі фонди, малий і середній бізнес. Зазначимо, що фандрайзингова діяльність вимагає відповідних умінь, навичок та компетентності від представників територіальних громад, розробки дієвої стратегії іiї реалізації, підтримки не лише місцевої влади, але й українського законодавця в контексті розробки прозорих механізмів ії реалізації. Однією із перспектив розвитку фандрайзингу соціальних проєктів в Україні є розвиток технологій інтернет-фандрайзингу та їх опанування представниками територіальних громад.

\section{Список використаних джерел}

1. Sandier M. W., Hudson D. A. Beyond the Bottom Line: How to Do More with Less in Nonprofit and Public Organizations. New York : Oxford University Press, 1998. 94 p.

2. Безверхнюк Т. М., Левицький А. О. Управління соціальними проектами: оцінка ризиків і аналіз зацікавлених сторін. Вісник Національної академії державного управління при Президентові України. 2013. № 4. С. 17-24.

3. Грабчак О. В. Фандрайзингова діяльність як альтернативний засіб залучення коштів у соціальну сферу. Науковий вісник Ужгородського наиіонального університету. Серія : Педагогіка. Сочіальна робота. 2014. Вип. 31. С. 51-54.

4. Грищенко Ю. И. Фандрайзинг как способ привлечения средств некоммерческой организации. Некоммерческие организачии в России. 2012. № 4. С. 42-48.

5. Карпунина А. В. Содержание и условия фандрайзинговой деятельности учреждений социального обслуживания населения : дис. ... канд. социол. наук : спец. 22.00 .03 «Экономическая социология и демография» / ФГБОУ ВО «Омский государственный технический университет». Нижний Новгород, 2017. 201 с.

6. Кривоносов А. Д. Основы теории связей с общественностью : учебник. Санкт-Петербург, 2008. $410 \mathrm{c}$.

7. Луков В. А. Социальное проектирование : учеб. пособие. Москва : Изд-во Московского гуманитарного университета : Флинта, 2007. 240 с.

8. Управління проектним циклом : навч. посіб. Київ : EuropeAid, 2004. 174 c.

9. Халий И., Лунева Л. Место под солнцем : пособие для экологических общественных организаций. Москва : СоЭС, 1998. 143 с.

10. Холостова Е. И. Генезис социальной работы в России : учеб. пособие. Москва : Дашков и К, 2017. 232 с. 


\section{References}

1. Sandier, M. W., Hudson D. A. (1998). Beyond the Bottom Line: How to Do More with Less in Nonprofit and Public Organizations. Oxford University Press.

2. Bezverkhniuk, T. M., Levytskyi A. O. (2013). Upravlinnia sotsialnymy proektamy: otsinka ryzykiv i analiz zatsikavlenykh stori [The social projects management: estimation of risks and analysis of skateholders]. Visnyk Natsionalnoi akademii derzhavnoho upravlinnia pry Prezydentovi Ukrainy Bulletin of the National Academy of Public Administration under the President of Ukraine, (4), pp. 17-24.

3. Hrabchak, O. V. (2014). Fandraizynhova diialnist yak alternatyvnyi zasib zaluchennia koshtiv u sotsialnu sferu [Fundraising activities as an alternative means of raising funds in the social sphere]. Naukovyi visnyk Uzhhorodskoho natsionalnoho universytetu. Seriia: Pedahohika. Sotsialna robotaScientific Bulletin of Uzhhorod University. Series "Pedagogy. Social Work", 31, pp. 51-54.

4. Grishchenko, Iu. I. (2012). Fandraizing kak sposob privlecheniia sredstv nekommercheskoi organizatsii [Fundraising as a way to raise funds for a non-profit organization]. Nekommercheskie organizatsii v Rossii - Non-profit organizations in Russia, (4), pp. 42-48.

5. Karpunina, A. V. (2017). Soderzhanie i usloviia fandraizingovoi deiatelnosti uchrezhdenii sotsialnogo obsluzhivaniia naseleniia [Content and conditions of fundraising activities of social service institutions] [PhD dissertation, FSBEI HE "Omsk State Technical University"].

6. Kryvonosov, A. D. (2008). Osnovy teorii sviazei s obshchestvennostiu [Fundamentals of the theory of public relations].

7. Lukov, V. A. (2007). Sotsialnoe proektirovanie [Social engineering]. Flinta.

8. Upravlinnia proektnym tsyklom [Project cycle management]. (2004). EuropeAid.

9. Khalii, I. (1998). Mesto pod solntsem [A place under the sun]. SoES/

10. Kholostova, E. I. (2017). Genezis sotsialnoi raboty v Rossii [The genesis of social work in Russia]. Dashkov and K.

Ревко Альона Миколаївна - доктор економічних наук, доцент, доцент кафедри соціальної роботи, Національний університет «Чернігівська політехніка» (вул. Шевченка, 95, м. Чернігів, 14035, Україна).

Ревко Алена Николаевна - доктор экономических наук, доцент, доцент кафедры социальной работы, Национальный университет «Черниговская политехника» (ул. Шевченко, 95, г. Чернигов, 14035, Украина).

Revko Alona - Doctor of Economics, Associate Professor, Associate Professor of the Department of Social Work, Chernihiv Polytechnic National University (95 Shevchenko St., Chernihiv, 14035, Ukraine).

E-mail: alohaha19@gmail.com

ORCID: http://orcid.org/0000-0001-7888-3657

ResearcherID: J-1377-2016

Чумак Катерина Юріївна - магістр, Національний університет «Чернігівська політехніка» (вул. Шевченка,

95 , м. Чернігів, 14035, Україна).

Чумак Екатерина Юрьевна - магистр, Национальный университет «Черниговская политехника» (ул. Шевченко, 95, г. Чернигов, 14035, Украина).

Chumak Kateryna - master student, Chernihiv Polytechnic National University (95 Shevchenko St., Chernihiv, 14035, Ukraine).

Ревко А., Чумак К. Фандрайзинг соціальних проєктів як інструмент соціального розвитку територіальних громад. Проблеми і перспективи економіки та управління. 2020. № 3(23). С. 57-64. 